\title{
MADRASAH DINIYAH SEBAGAI POLA DISEMINASI ISLAM MODERAT DI PESANTREN MAHASISWA DARUSSALAM KEPUTIH SURABAYA
}

\author{
Zumrotul Mukaffa \\ (UIN Sunan Ampel Surabaya)
}

\begin{abstract}
Abstrak:
Tulisan ini mencoba mengurai peran penting Madrasah Diniyah dibawah naungan Pesantren Darussalam Keputih yang berada di lingkungan Institut Teknologi Sepuluh November (ITS) Surabaya di tengah-tengah maraknya gerakan Islam transnasional di dalam kampus. Pengelola menyadari sepenuhnya arti penting diseminasi tata nilai Islam moderat dan menempatkan Madrasah Diniyah sebagai struktur mediasi dalam membiakkan nilai-nilai toleransi dan menolak formalisasi khilafah dalam bingkai Negara Kesatuan Republik Indonesia. Para santri tidak hanya belajar kitab-kitab berdasarkan jenjang kelas masing-masing, melainkan juga mendalami gagasan besar Islam moderat di tanah air. Pendalaman dilakukan dengan cara menghubungkan pengetahuan santri dengan website WIKI ASWAJA dan ASWAJA NU yang dikelola oleh Pusat Kajian Aswaja PWNU Jawa Timur. Isu-isu mutakhir, seperti khilafah dan Islam Nusantara yang dipublikasikan oleh website didiskusikan dengan metode bandongan-muhāwarah dengan melibatkan seluruh santri-mahasiswa. Keberhasilan Madrasah Diniyah Takmiliyah di pesantren Darussalam sebagai struktur mediasi ditandai oleh kemampuannya mengembangkan diskursus tandingan terhadap gerakan-gerakan Islam transnasional di lingkungan kampus.
\end{abstract}

Kata Kunci: Pesantren Darussalam; Madrasah Diniyah Takmiliyah; Islam Moderat; Toleransi; Formalisasi Khilafah. 


\begin{abstract}
:
This paper attempts to unravel the important role of the Madrasah Diniyah under Darussalam Islamic Boarding School Keputih within the 10 November Institute of Technology Surabaya (ITS) environment with transnational Islamic movement. The organizers are fully aware of the importance of disseminating moderate Islamic values and positioning Madrasah Diniyah as mediation structure to develop tolerance and to counter the formalization of khilafah within the Unitary State of the Republic of Indonesia. The santri did not only study a collection of kitab based upon their levels, but also explore the great ideas of moderate Islam in the country. The enrichment process was managed by reflecting students' knowledge with WIKI ASWAJA and ASWAJA NU websites, managed under PWNU Aswaja Study Center in East Java. Recent issues, such as the Caliphate and Islam Nusantara on the website are discussed with the bandongan-muhäwarah method by involving all santri. The success of the Madrasah Diniyah Takmiliyah in the pesantren Darussalam as a mediating structure was marked by its ability to develop counter-discourse towards transnational Islamic movements in campus environment.
\end{abstract}

\title{
Keywords: Pesantren Darussalam; Diniyah Takmiliyah Madrasah; Moderate Islam; Tolerance; Formalization of Caliphate.
}

\section{A. Pendahuluan}

Peran penting Pesantren Mahasiswa untuk menyediakan wacana tanding (counter-discourse) radikalisasi Islam nyaris terabaikan dalam kajian akademis. Berbagai penelusuran yang selama ini mengemuka, seringkali hanya berkutat pada radikalisasi Islam yang menguat di kampus, gerakan-gerakan Islam transnasional, ideologisasi, dan aksi-aksi yang dilakukan oleh mereka, termasuk yang lekat dengan kekerasan dan teror atas nama agama. Pada saat yang sama, pengkajian juga lebih menitik beratkan pada analisis terhadap program-program deradikalisasi, baik yang dilakukan oleh Negara maupun organisasi sosial keagamaan.

Gerakan radikalisasi Islam di kampus-kampus Perguruan Tinggi Umum (PTU), terutama yang memiliki reputasi tinggi di mata publik, seperti Institut Teknologi Bandung (ITB), Universitas Gajah Mada (UGM) Yogjakarta, Institut Teknologi Surabaya (ITS), Universitas Erlangga (Unair) Surabaya, Universitas Brawijaya (UB) Malang, dan seterusnya mengalami perkembangan yang luar biasa. Proses transformasi doktrin dan ideologi tidak hanya merambah ke lingkungan mahasiswa, melainkan juga dosen, dan bahkan kalangan pejabat kampus. Keluarnya dokumen tentang struktur organisasi Hizbut Tahrir Indonesia (HTI) memberi petunjuk penting banyaknya elit sivitas akademika 
kampus yang menjadi bagian didalam organisasi trans-nasional tersebut. ${ }^{1}$ Demikian pula, teridentifikasinya pelaku bom bunuh diri di Surabaya tahun 2018 yang melibatkan satu keluarga menjadi petunjuk penting menguatnya radikalisasi Islam di PTU. Pelaku bom bunuh diri mulai mengenal doktrin dan doktrin Islam yang mengabsahkan tindakan bunuh diri sebagai manifestasi jihad pada saat belajar di kampusnya. ${ }^{2}$

Berbagai varian gerakan Islam trans-nasional diklaim sebagai pengusung utama radikalisasi Islam. ${ }^{3}$ Mereka tidak lah tunggal secara doktrinal, ideologi maupun gerakannya. Namun, secara keseluruhan trans-nasionalisme Islam memiliki kecenderungan doktriner-ideologis yang sama, yaitu: menolak sistem keyakinan yang melekat dalam Islam moderat. Melalui proses yang sangat intensif dan didukung oleh semangat konstitusionalisme kebebasan berdemokrasi di tanah air, Islam trans-nasional mengalami perkembangan yang luar biasa. Mereka bukan saja berhasil merekrut simpatisan baru dari kalangan masyarakat biasa, melainkan juga penguasaha dan bahkan, aparatur sipil Negara (ASN). Termasuk diantaranya yang telah terpapar gerakan Islam trans-nasional adalah para dosen dan pejabat struktural kampus yang berstatus sebagai ASN. ${ }^{4}$

1 Anonim, Daftar Nama Pengurus dan Simpatisan HTI Merupakan Pegawai Pemerintah (ASN, TNI, Polri), Akademisi (PTS dan PTN), (Tk: Tp, tt). Mengenai dokumen dimaksud, pihak HTI tidak membantah atau membenarkannya.

2 Rezki Alvionitasari dan Endri Kurniawati,"Peledak Bom di Surabaya Punya Gen Teroris, Siapa?," TEMPO.CO, 17 Mei 2018, Diakses 24 Agustus 2018, https://nasional.tempo.co/read/1089969/peledak-bom-di-surabaya-punya-gen-teroris-siapa.

3 Salah satu definisi sangat terkenal diajukan oleh Rabassa et. al yang menegaskan radikalisasi sebagai "the process of adopting an extremist belief system, including the willingness to use, support, or facilitate violence, as a method to effect societal change". Radikalisasi Islam, dengan demikian, menunjuk pada proses beralihnya sistem keyakinan keagamaan lama menuju pada kepercayaan terhadap nilai-nilai, doktrin atau ideologi baru. Sistem keyakinan baru seringkali cenderung mengarahkan ke ekstrimisme dalam beragama, atau setidaknya, menggunakan, mendukung maupun memfasilitasi aksi-aksi kekerasan. Dapat pula, sistem keyakinan baru memberikan arah untuk mengembangkan metode dalam kerangka mewujudkan perubahan sosial dan struktural secara mendasar. Angel Rabasa et al., Deradicalizing Islamist Extremists (Santa Monica, CA: The RAND Corporation, 2010), 1.

4 Untuk beberapa kasus di PTU Jawa Timur dapat dirujuk, diantaranya: Hilda Meilisa Rinanda, "Viral, 4 Dosen di Surabaya Tolak Pembubaran HTI," detiknews, 08 Mei 2018, Diakses 24 Agustus 2018, https://news.detik.com/jawatimur/4010598/viral-4-dosen-disurabaya-tolak-pembubaran-hti; Yusuf Muhammad, "Menghawatirkan, Viral Tokoh HTI Kampus ITS Mulai Dosen, Kaprodi, hingga Guru Besar," DUTAISLAM.com, 08 Mei 2018, Diakses 24 Agustus 2018, http://www.dutaislam.com/2018/05/menghawatirkan-viraltokoh-hti-kampus-its-mulai-dosen-kaprodi-hingga-guru-besar.html; Achmad Faizal, "Dosen ITS: Saya Bukan HTI, Saya Tidak Punya Kepentingan dengan HTI," KOMPAS.com, 08 Mei 2018, Diakses 24 Agustus 2018,

https://regional.kompas.com/read/2018/05/08/17193701/dosen-its-saya-bukan-htisaya-tidak-punya-kepentingan-dengan-hti; Deni Prastyo Utomo, "Rektor Unair: Dosen yang Tolak Pembubaran HTI Sedang Diklarifikasi," detiknews, 08 Mei 2018, Diakses 24 Agustus 
Terpaparnya ASN di lingkungan kampus umum tidak lepas dari intesifnya radikalisasi Islam yang nyaris tanpa kontrol. Melalui kader-kader dan aktor-aktor utama, gerakan Islam trans-nasional menawarkan sistem keyakinan baru kepada para mahasiswa dan civitas akademika lainnya. Salah satu varian Islam trans-nasional yang cukup sukses menjalankan proyek radikalisasi Islam di kampus adalah Hizbut Tahrir Indonesia (HTI). ${ }^{5}$ Sistem keagamaan yang diusungnya, di satu sisi, tidak toleran terhadap penggunaan, dukungan atau fasilitasi terhadap kekerasan dengan berbagai manifestasinya. Di sisi lain, tata nilai, doktrin maupun ideologi yang dibawanya mengarahkan pada proses perwujudkan perubahan secara mendasar terhadap struktur sosial maupun tata pemerintahan. Keseluruhan struktur sosial dan tata pemerintahan didekonstruksi total menjadi sistem khilafah Islamiyah. ${ }^{6}$

Kampus menjadi salah satu tempat paling nyaman bagi HTI untuk melakukan radikalisasi Islam kepada civitas akademikanya. Dengan leluasa, aktifis-aktifis HTI menstransformasikan ideologi Khilafah Islamiyah kelangan civitas kampus, terutama mahasiswa baru dan dosen-dosen muda potensial dan cemerlang. Seperti yang dilakukan pendahulunya, Abdurrahman al-Baghdadi, HTI menggunakan dua metode utama untuk melakukan proses radikalisasi. Pertama, membentuk kelompok studi terbatas (halaqah) dibawah pendampingan langsung aktifis senior maupun mentor HTI dari dalam dan luar kampus. Kedua, menyusun dan mengimplementasikan pelatihan-pelatihan

2018, https://news.detik.com/berita-jawa-timur/d-4010766/rektor-unair-dosen-yangtolak-pembubaran-hti-sedang-diklarifikasi.

${ }^{5}$ Selain HTI, Tarbiyah atau Ikhwanul Muslimin (IM) juga merupakan gerakan Islam transnasional yang cukup berhasil melakukan radikalisasi di kampus-kampus umum ternama di tanah air. Salah satu keberhasilan mereka adalah menguasai Lembaga Dakwah Kampus (LDK) dan Badan Eksekutif Mahasiswa (BEM) dan membentuk jaringan antar kampus di seluruh tanah air. Sebagai institusi mediasi yang sangat efektif untuk mentransformasikan doktrin dan ideologi Islam, kedua lembaga ini juga menjadi incaran aktifis-aktifis HTI, sehingga seringkali terjadi perebutan antara Tarbiyah IM dan HTI di beberapa kampus. Richard G. Kraince, "The Role of Islamic Student Groups in the Reformasi Struggle: KAMMI (Kesatuan Aksi Mahasiswa Muslim Indonesia", Studia Islamika, Vol. 7, No. 1 (2000), 3-50; Yon Machmudi, "The Emergence of New Santri in Indonesia", Journal of Indonesian Islam, Vol. 2, No. 01 (June 2008), 69-102; Burhanuddin Muhtadi, "The Quest for Hizbut Tahrir in Indonesia", Asian Journal of Social Science 37 (2009), 628.

${ }^{6}$ Khilafah Islamiyah menunjuk pada sistem pemerintahan Islam yang berlaku di seluruh dunia, sebagaimana yang pernah terjadi pada abad pertengahan. Proses mewujudkan sistem tersebut dilakukan dengan "revolusi damai yang Islami" (Islamic peace revolution) yang termanifestasikan kedalam tiga tahapan, yaitu: tahapan pembentukan kader (marhalah altathqïf), tahapan sosialisasi dan interaksi (marhalah al-tafá'ul ma'a al-nās), dan tahapan transformasi-revolusi (marhalah al-istislām al-hukm). Uraian secara mendalam tentang tahapan pembentukan khilafah Islamiyah dapat dirujuk dalam Muhammad Mushin Radli, Muhammad Muhsin Radli, Hizb al-Tahr̄r, Tsaqāfatuhu wa Manhājuhu fí Iqāmah al-Daulah alKhilāfah al-Islāmiyah, (Baghdad: Kuliyah al-Ushūluddin-al-Jāmi' ah al-Islāmiyah, 2006), 293324. 
keagamaan khusus secara berkala (daurah) yang secara spesifik berorientasi pada penanaman ideologi khilafah Islamiyah. ${ }^{7}$ Keleluasaan transformasi proyek radikalisasi Islam, terutama di PTU baru menemui batu sandungan, seiring dengan pencabutan status badan hukum HTI oleh pemerintah melalui Kementerian Hukum dan Hak Asasi Manusia (Kemenkum-HAM) pada 19 Juli

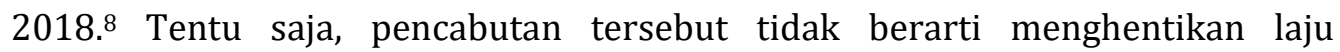
perjalanan radikalisasi Islam di kampus, melainkan hanya sekedar menghambat eskalasi percepatannya.

Dalam konteks dinamika radikalisasi Islam di PTU, eksistensi pesantren mahasiswa menarik untuk dikaji. Secara kelembagaan, kehadirannya merupakan salah satu entitas yang berinteraksi langsung dengan civitas akademika, terutama para mahasiswa terpapar radikalisasi Islam. Setidaknya, terdapat potensi kerentanan dan sekaligus keberuntungan masuknya mereka ke lingkungan pesantren. Mereka akan mentransformasikan doktrin, ideologi, dan aktifitas gerakan Islam radikal kepada kalangan mahasiswa lainnya maupun masyarakat pesantren secara umum. Di lain pihak, kehadiran mereka juga menjadi keberuntungan tersendiri bagi penyelenggara pesantren mahasiswa. Kehadirannya dapat memerankan diri sebagai institusi deradikalisasi Islam ke kalangan mahasiswa dengan menyediakan wacana tanding terhadap penyebaran doktrin-doktrin Islam radikal.

Salah satu wacana tanding (yang dikembangkan adalah diskursus Islam moderat atau moderatisme Islam. Meski relatif kesulitan dalam mendefinisikan secara baku yang dapat disepakati oleh semua pihak tentang Islam moderat, tetapi setidaknya secara substantif dapat diterima berbagai pihak, adalah doktrin dan gerakan yang selalu mencerminkan tata nilai toleransi yang bersumber dari sumber-sumber Islam otentik. Wacana tanding ini telah ditumbuhkembangkan oleh Pesantren Darussalam Keputih Surabaya yang berdekatan dengan kampus ITS. Tulisan ini mencoba menelusuri pola diseminasi tata nilai Islam moderat kepada para santri yang berstatus sebagai mahasiswa.

\section{B. Islam Moderat dalam Perdebatan}

Sebagai diskursus, Islam moderat menjadi perbincangan serius bukan saja para pakar, melainkan juga Majelis Ulama Indonesia dan para aktifis Islam. Eksistensi dan manifestasinya selama ini merepresentasikan karakter khas Islam

\footnotetext{
${ }^{7}$ Muhtadi, "The Quest for Hizbut Tahrir in Indonesia”, 626; Asep Muhamad Iqbal and Zulkifli, "Islamic Fundamentalism, Nation-state and Global Citizenship: The Case of Hizb ut-Tahrir", Indonesian Journal of Islam and Muslim Societies, Vol. 6, no.1 (2016), 35-61; Gwenaël NjotoFeillard, Hizbut Tahrir Indonesia in 2014: The Political Economy of Discontent, (Singapore: The ISEAS-Yusof Ishak Institute, 2015); Indriana Kartini, "Hizbut Tahrir Indonesia and the Idea of Restoring Islamic Caliphate”, Masyarakat Indonesia, Vol. 41, No. 1 (Juni 2015), 1-14. ${ }^{8}$ Ahmad Najib Burhani, "The Banning of Hizbut Tahrir and the Consolidation of Democracy in Indonesia", ISEAS Perspective, No. 71 (September 2017), 1-10.
} 
Indonesia yang terbukti secara historis mampu menjaga kemajemukan konstruksi Negara-Bangsa, terutama dari aspek kepercayaan dan keagamaan. Seiring dengan perjalanan Indonesia sebagai Negara-bangsa modern di masa yang akan datang, Islam moderat diharapkan tetap menjadi manifestasi dari perilaku keberagamaan masyarakat muslim di tengah kuatnya desakan dan gerusan model keberislaman baru yang bercorak trans-nasional. ${ }^{9}$

Secara terminologis, Islam moderat seringkali dipadankan dengan Islam wasathiyah. Hanya saja, definisi baku masih menjadi perdebatan di kalangan para pakar, aktifis muslim, maupun organisasi sosial keagamaan. Beberapa pakar sepakat dengan John L. Esposito bahwa, Islam moderat merupakan kosa kata teknis yang sangat diperebutkan maknanya (highly contested concept), baik di lingkungan umat Islam maupun non-muslim. Definisi yang muncul sangat beragam, tergantung siapa dan dalam konteks apa, ia didefinisikan dan dipahami. ${ }^{10}$

Secara historis, perdebatan definisi Islam moderat mulai mengemuka di dunia internasional dan pada tahap selanjutnya merembet ke tanah air, seiring dengan diadakannya pertemuan akademik di Amerika Serikat pada tahun 2004. Dalam pertemuan tersebut, terjadi perdebatan serius dikalangan pakar terkait dengan definisi dan aktor Islam moderat. Ariel Cohen yang juga menjabat peneliti senior di The Heritage Foundation mendefinisikan Islam moderat sebagai

${ }^{9}$ Islam trans-nasional secara terminologis merupakan istilah baru yang mengemuka dan masih menjadi perdebatan hingga saat ini. Karena pada dasarnya, Islam sejak era Rasul Muhammad sudah bercorak trans-nasional, tepatnya, ketika agama ini mulai ekspansi ke luar wilayah Makkah dan Madinah. Disatu sisi, trans-nasionalisme Islam dipahami lebih dalam konteks migrasi dari satu Negara tertentu ke Negara lainnya. Karen Leonard, "Transnational and Cosmopolitan Forms of Islam in the West", Harvard Middle Eastern and Islamic Review 8 (2009), 176. Di sisi lain, seperti halnya diwakili oleh Bowen, mendefinisikan Islam trans-nasional dalam tiga pengertian, yaitu: pergerakan demografis (demographic movement), lembaga-lembaga keagamaan trans-nasional (transnational religious movement), dan perpindahan rujukan dan perdebatan gagasan, doktrin, dan ideologi yang melampaui batas Negara (the field of religious reference and debate). J.R. Bowen, "Beyond Migration: Islam as a Transnational Public Space", Journal of Ethnic and Migration Studies, Vol. 30, No. 5 (2004), 1-14. Definisi Brown ini banyak mempengaruhi para intelektual di tanah air yang concerns terhadap fenomena menguatnya trans-nasionalisme, terutama dalam konteks jejaring lintas Negara dan perpindahan gagasan, doktrin maupun ideologi keagamaan. Abdurrahman Wahid, ed., Ilusi Negara Islam, Ekspansi Gerakan Islam Transnasional di Indonesia, (Jakarta: The Wahid Institute, 2009); Ahmad Syafi'i Mufid, Perkembangan Paham Keagamaan Transnasional di Indonesia, (Jakarta: Badan Litbang dan Diklat Kementerian Agama RI, 2011).

${ }^{10}$ Danial Hilmi, “Mengurai Islam Moderat sebagai Agen Rahmatan Lil 'Alamin”, dalam M. Zainuddin dan Muhammad In'am Esha dkk., Islam Moderat, Konsepsi, dan Aksi, (Malang: UIN Maliki Press, 2016), 62; Toto Suharto, "Gagasan Pendidikan Muhammadiyah dan NU sebagai Potret Pendidikan Islam Moderat di Indonesia”, Islamica: Jurnal Studi Keislaman, Vol. 9, No. 1 (September 2014): 81-109, 27; Toto Suharto, "Indonesianisasi Islam: Penguatan Islam Moderat dalam Lembaga Pendidikan di Indonesia”, Al-Tahrir, Vol. 17, No. 1 (Mei 2017): 155-178, 19. 
seorang muslim yang tidak sependapat bahwa jihad akbar sebagai tiang maupun dimensi utama keimanan. Sebaliknya, muslim yang moderat adalah mereka yang selalu mengedepankan dialog dan kompromi terhadap muslim lain yang memiliki penafsiran berbeda terhadap al-Qur'an dan komunitas non-muslim. ${ }^{11}$

Cohen menambahkan, muslim moderat juga tidak akan mendukung aksiaksi kekerasan terhadap komunitas syi'ah, sufi, Kristian, Yahudi, dan Hindu. Sebaliknya, ia sangat menghormati hak-hak individu untuk berbeda pandangan, beribadah kepada Allah dengan cara yang mereka pilih, ataupun untuk tidak beribadah dan bahkan untuk tidak beriman. Muslim moderat adalah dia yang ingin mengajak saudaranya kepada iman dengan cinta dan akal, bukan dengan ancaman-ancaman ataupun paksaan senjata. Muslim moderat mengutuk bom bunuh diri dan operasi-operasi teroris dan mengecam ulama-ulama yang mengindoktrinasi absahnya tindakan kejam. ${ }^{12}$

John L. Esposito memiliki definisi berbeda dengan Islam atau muslim moderat, baik sebagai individu maupun bagian dari komunitas muslim. Menurutnya, mereka yang menjadi bagian dari kaum moderat merupakan invidu yang yang hidup dan bekerja di dalam masyarakat, mencari perubahan dari bawah, menolak ekstrimisme keagamaan, dan menganggap kekerasan dan terorisme sebagai tidak sah. Kaum moderat, dengan cara yang berbeda, menafsirkan Islam untuk merespons secara lebih efektif realitas-realitas keagamaan, sosial, politik dari masyarakat mereka dan urusan-urusan internasional. Sedangkan Moqtedar Khan lebih melihat Islam moderat sebagai seseorang yang berada pada posisi tengah secara politik, tidak di kanan dan kiri ekstrim (a person who takes a position in the political sphere), dan mengutamakan ijtihad ketimbang jihad. 13

Bukan saja di Barat, perdebatan Islam moderat juga mengemuka di tanah air, baik di kalangan pakar, aktifis Islam maupun organisasi sosial keagamaan (Ormas) Islam. PPIM UIN Syarif Hidayatullah Jakarta, salah satunya, mendefinisikan Islam moderat sebagai corak Islam yang ramah, toleran, inkulsif, dan menjunjung tinggi nilai-nilai kemanusiaan dan keadilan. ${ }^{14}$ Muhammad Ali mengajukan definisi hampir sama dengan PPIM dengan mengatakan, Islam moderat adalah individu yang "do not share the hard-line visions and actions". Artinya, Islam moderat menunjuk pada komunitas Islam yang mengedepankan perilaku normal (tawassut) di dalam mengimplementasikan ajaran agama yang mereka tegakkan, toleran terhadap perbedaan pendapat, menghindari

\footnotetext{
11 PPIM UIN Jakarta, Pemberdayaan Islam Moderat dalam Konteks Hubungan Luar Negeri, (Jakarta: Pusat Pengkajian Islam dan Masyarakat (PPIM) Universitas Islam Negeri (UIN) Jakarta-Badan Pengkajian dan Pengembangan Kebijakan Departemen Luar Negeri, 2006), 9. 12 PPIM UIN Jakarta, Pemberdayaan Islam Moderat, 6.

13 PPIM UIN Jakarta, Pemberdayaan Islam Moderat, 7.

14 PPIM UIN Jakarta, Pemberdayaan Islam Moderat, 8.
} 
kekerasan, dan memprioritaskan pemikiran dan dialog sebagai strateginya. Sementara Burhani lebih menekankan konteks madzhab pemikiran dalam mendefinisikan Islam moderat. Menurutnya, Islam moderat menunjuk "midposition between liberalism and Islamism" yang berarti individu maupun organisasi yang berada di tengah-tengah antara madzhab liberalisme dan Islamisme. ${ }^{15}$

Beberapa aktifis Islam, seperti Abdurrahman Wahid et.al memiliki perspektif berbeda tentang definisi Islam moderat. Menurutnya, definisi Islam moderat dibedakan dalam konteks individu dan kelembagaan. Dalam konteks individu, Islam moderat dipahami sebagai setiap muslim yang:

Yang menerima dan menghargai pandangan dan keyakinan yang berbeda sebagai fitrah; tidak mau memaksakan kebenaran yang diyakininya kepada orang lain, baik secara langsung atau melalui pemerintah; menolak cara-cara kekerasan atas nama agama dalam bentuk apa pun; menolak berbagai bentuk pelarangan untuk menganut pandangan dan keyakinan yang berbeda sebagai bentuk kebebasan beragama yang dijamin oleh Konstitusi negara kita; menerima Dasar Negara Pancasila sebagai landasan hidup bersama dan bentuk Negara Kesatuan Republik Indonesia (NKRI) sebagai konsensus final dalam kehidupan berbangsa dan berngera yang melindungi perbedaan dan keragamaan yang ada di tanah air. ${ }^{16}$

Sedangkan dalam konteks kelembagaan, maka Islam moderat menunjuk pada "kelompok yang memiliki karakteristik seperti yang tercermin dalam karakteristik individu moderat, ditambah dengan visi dan misi organisasi yang menerima Dasar Negara Pancasila sebagai landasan hidup bersama bangsa Indonesia dan bentuk Negara Kesatuan Republik Indonesia (NKRI) sebagai konsensus final dalam kehidupan berbangsa dan bernegara. ${ }^{17}$

Ma'ruf Amin yang juga Ketua Umum Majelis Ulama Indonesia (MUI) memberikan definisi yang lebih menitik beratkan pada kharakteristik muslim sebagai individu maupun organisasi yang moderat. Hanya saja, ia memilih menggunakan kosa kata teknis "Islam wasathiyah" sebagai padanan Islam moderat. Dalam pidato Pembukaan Rakernas MUI di Ancol, Jakarta, 10 November 2015 dalam kapasitasnya sebagai Ketua MUI, ia menegaskan Islam wasathiyah menunjuk pada individu yang mengaksentuasikan keberislamannya dengan mengambil jalan tengah (tawassuth), berkeseimbangan (tawazun), lurus dan tegas (i'tidal), toleransi (tasamuh), egaliter (musawah), mengedepankan musyawarah (syura), berjiwa reformasi (islah), mendahulukan yang prioritas (aulawiyah), dinamis dan inovatif (tathawwur wa ibtikar), dan berkeadaban

15 Suharto, "Gagasan Pendidikan Muhammadiyah", 88-89.

16 Wahid ed., Ilusi Negara Islam, 46.

17 Wahid ed., Ilusi Negara Islam, 46-47. 
(tahadhdhur). ${ }^{18}$ Sepuluh sifat yang menjadi karakteristik keber-Islam-an sebagian besar muslim Indonesia dengan beragam organisasi masyarakat yang menaunginya, diharapkan menjadi perekat kehidupan beragama, berbangsa, dan bernegara yang selama ini telah dirajut oleh Majelis Ulama' Indonesia yang berperan sebagai representasi masyarakat muslim seluruh Indonesia. Seorang muslim selayaknya senantiasa mengambil jalan tengah dalam memahami ajaran agamanya, seimbang dalam menjalani laku duniawi dan ukhrawi, lurus dan tegas melaksanakan hak dan memenuhi kewajibannya, toleran dan menghormati perbedaan dalam kehidupan bermasyarakatnya, tidak bersikap diskriminatif dalam memandang berbagai aspek perbedaan manusia, menyelesaikan setiap persoalan dengan jalan musyawarah, lebih mengutamakan prinsip reformatif untuk mencapai keadaan lebih baik, mampu memilih dan mengutamakan yang menjadi prioritas dalam urusan keummatan, responsif terhadap perubahan zaman dengan menciptakan inovasi baru, dan berkeadaban yang luhur, sehingga menjadi teladan tidak hanya di kalangan masyarakat muslim tetapi lintas agama, etnis, bahkan benua. ${ }^{19}$

\section{Sementara Din Syamsuddin mengatakan:}

"Islam Washathiyah sekarang menjadi pembicaraan dunia, menjadi lirikan dari luar Islam. Wasathiyah adalah semua wawasan yang menekankan kecenderungan untuk berada pada jalan tengah. Ada yang menafsirkan wasathiyah, sebagai as-shirath alMustaqim, sebagaimana bacaan surah al-Fatihah di tiap shalat, berarti jalan lurus".

Konsep jalan tengah itu tak sama dengan konsep the middle way/the middle path di bidang ekonomi konvensional. Wasthiyah dalam Islam bertumpu pada tauhid sebagai ajaran Islam yang mendasar yang juga sekaligus menegakkan keseimbangan dalam penciptaan dan kesatuan dari segala lingkaran kesadaran manusia. Hal ini membawa pemahaman tentang adanya korespondensi antara Pencipta dan ciptaan (al-'alaqah bain al-Khaliq wa alMakhluq) sekaligus analogi antara makrokosmos dan mikrokosmos (al-qiyas bain al-'Alam al-kabir wa al'Alam as-Shaghir) menuju satu spot, titik tengah (median position).

Dengan demikian, sesuai filosofi wasathiyah di atas, Islam menolak segala bentuk ektremitas, menentang berbagai penyimpangan pemikiran, baik dalam

\footnotetext{
${ }^{18}$ Ma'ruf Amin, "Paradigma Islam Wasathiyah, Ruh Gerakan MUI Semua Tingkatan", Mimbar Ulama, Majelis Ulama Indonesia, Edisi 372, Rabi'ul Awal 1437 H/Februari 2016 M, 11.

19 "Taujihat Surabaya, Islam Wasathiyah untuk Indonesia dan Dunia yang Berkeadilan dan Berkeadaban”, Mimbar Ulama, Majelis Ulama Indonesia, Edisi 372, Rabi'ul Awal 1437 M/Februari 2016, 15.
} 
sosial, ekonomi, politik, dan budaya karena itu bertentangan dengan watak Islam yang sejati tadi. 20

Sungguh pun terdapat perbedaan dalam mendefinisikan Islam moderat, namun secara substansial memiliki kesamaan pandangan. Islam moderat dengan mengacu pada keseluruhan definisi di atas, dimaknai sebagai individu maupun organisasi yang dalam menjalankan keber-Islam-an menolak ekstrimisme dalam berbagai manifestasinya. Penolakan ekstrimisme meliputi ekstrimisme pemikiran, doktrin, dan ideologi yang berbasis pada Islam, pandangan terhadap barat, demokrasi dan Hak Asasi Manusia (HAM), dan sikap terhadap perbedaan etnik, ras, keyakinan maupun keagamaan dengan berdasarkan pada prinsip-prinsip keadilan. Sikap dan perilaku yang menjauh dari ekstrimisme ini akan melahirkan pola keber-Islam-an yang inklusif, toleran, dan mengedepankan dialog ketimbang aksi-aksi kekerasan maupun segala bentuk teror berbaju agama.

Bukan saja pada pemaknaan, silang pendapat juga mengemuka disekitar prinsip yang melekat dalam Islam moderat. KH Ahmad Shiddiq, salah satunya, mengajukan prinsip jalan tengah (al-tawassuth) sebagai pembentuk muslim moderat. Ia menegaskan:

Tawassut (termasuk i'tidâl dan tawâzun) bukanlah serba kompromistis dengan mencampuradukkan semua unsur (sinkretisma). Juga bukan mengucilkan diri dari menolak pertemuan dengan unsur apa-apa. Karakter tawassut bagi Islam adalah memang sejak semula Allah sudah meletakkan di dalam Islam segala kebaikan, dan segala kebaikan itu sudah pasti terdapat di antara ujung tațarruf, sifat mengujung, ekstremisma. Prinsip dan karakter tawassut yang sudah menjadi karakter Islam ini harus diterapkan dalam segala bidang, supaya Agama Islam dan sikap serta tingkah laku umat Islam selalu menjadi saksi dan pengukur kebenaran bagi semua sikap dan tingkah laku manusia umumnya. ${ }^{21}$

Said Aqil menempatkan prinsip i'tidal dan tawāzun secara mandiri dengan tawassuth, meskipun ketiganya menjadi satu kesatuan tak terpisahkan. Prinsip tawassuth memiliki signifikansinya, terutama dalam konteks pengambilan keputusan hukum. Prinsip ini mencerminkan seorang muslim maupun organisasi yang dalam pengambilan keputusan (istinbäth) tidak semata-mata menggunakan nash, melainkan juga posisi rasio. Begitu pula, respon terhadap berbagai madzhab pemikiran, doktrin dan ideologi keagamaan selalu mencerminkan sikap tengah antara tekstual dan rasio. Sementara prinsip tawāsun menunjuk pada satu

20 Din Syamsuddin, "Islam Wasathiyah, Solusi Jalan Tengah", Mimbar Ulama, Majelis Ulama Indonesia, Edisi 372, Rabi'ul Awal 1437 H/Februari 2016 M, 7.

${ }^{21}$ Toto Suharto, "Gagasan Pendidikan Muhammadiyah", 103. 
pandangan yang selalu menjaga keseimbangan, terutama dalam konteks berpolitik, berbangsa, dan bernegara. I'tidāl direpresentasikan oleh sikap dan perilaku sosial-keagamaan muslim yang toleran, baik kepada sesama ahl alqiblah maupun non-muslim. ${ }^{22}$

MUI mengajukan prinsip-prinsip, kharakteristik maupun ciri khusus Islam wasathiyah (moderat) lebih luas dibanding sebelumnya. Pertama, Tawassuth (mengambil jalan tengah), yaitu pemahaman dan pengamalan yang tidak ifrath (berlebih-lebihan dalam beragama) dan tafrith (mengurangi ajaran agama). Kedua, Tawazun (berkeseimbangan), yaitu pemahaman dan pengamalan agama secara seimbang yang meliputi semua aspek kehidupan, baik duniawi maupun ukhrawi, tegas dalam menyatakan prinsip yang dapat membedakan antara inhiraf (penyimpangan) dan ikhtilaf (perbedaan). Ketiga, I'tidal (lurus dan tegas), yaitu menempatkan sesuatu pada tempatnya dan melaksanakan hak dan memenuhi kewajiban secara proporsional. Keempat, Tasamuh (toleransi), yaitu mengakui dan menghormati perbedaan, baik dalam aspek keagamaan dan berbagai aspek kehidupan lainnya. Kelima, Musawah (egaliter), yaitu tidak bersikap diskriminatif pada yang lain disebabkan perbedaan keyakinan, tradisi dan asal usul seseorang. Keenam, Syura (musyawarah), yaitu setiap persoalan diselesaikan dengan jalan musyawarah untuk mencapai mufakat dengan prinsip menempatkan kemaslahatan di atas segalanya. Ketujuh, Islah (reformasi), yaitu mengutamakan prinsip reformatif untuk mencapai keadaan lebih baik yang mengakomodasi perubahan dan kemajuan zaman dengan berpijak pada kemaslahatan umum (mashlahah 'amah) dengan tetap berpegang pada prinsip al-muhafazhah 'ala alqadimi al-shalih wa al-akhdzu bi al-jadidi al-ashlah (mempertahankan tradisi lama yang baik dan mengambil tradisi baru yang lebih baik). Kedelapan, Aulawiyah (mendahulukan yang prioritas), yaitu kemampuan mengidentifikasi hal ihwal yang lebih penting harus diutamakan untuk diimplementasikan dibandingkan dengan yang kepentingannya lebih rendah. Kesembilan, Tathawwur wa Ibtikar (dinamis dan inovatif), yaitu selalu terbuka untuk melakukan perubahan-perubahan sesuai dengan perkembangan zaman serta menciptakan hal baru untuk kemaslahamatan dan kemajuan umat manusia. Kesepuluh, Tahadhdhur (berkeadaban), yaitu menjunjung tinggi akhlakul karimah, karakter, identitas, dan integritas sebagai khairu ummah dalam kehidupan kemanusiaan dan peradaban. ${ }^{23}$

22 Said Aqiel Siraj, Ahlusunnah wal Jama'ah Dalam Lintasan Sejarah, (Yogyakarta: Penerbit LKPSM, 1997), 20-21.

${ }^{23}$ Majelis Ulama Indonesia, "Taujihat Surabaya, Islam Wasathiyah untuk Indonesia dan Dunia yang Berkeadilan dan Berkeadaban", Mimbar Ulama, Majelis Ulama Indonesia, Edisi 372, Rabi'ul Awal 1437 M/Februari 2016, 15. 
Secara substansial, tidak ada perbedaan perspektif tentang prinsipprinsip Islam moderat. Perbedaan terjadi hanya pada jumlah prinsip dan bahasa yang digunakan untuk menerjemahkannya. Seluruhnya sepakat bahwa, selalu dalam posisi tengah (tawassuth) merupakan prinsip utama untuk membentuk sikap dan perilaku muslim moderat. Proses aktualisasi prinsip ini membutuhkan prinsip lain yang mendukungnya, seperti tawa>zun yang juga dapat diterjemahkan sebagai "netral, batas kewajaran, selalu mempertimbangkan segala sesuatunya". Tidak mungkin muslim akan mampu berada dalam posisi tengah dalam merespon dinamika keagamaan, sosial, kemasyarakatan, kebangsaan, dan kenegaraan, jika sejak awal sudah memiliki sikap tidak netral atau emosional tanpa pertimbangan. Dengan demikian, prinsip-prinsip selain tawassuth merupakan prinsip derivatif.

Perbedaan definisi maupun prinsip yang dapat membentuk sikap dan perilaku moderat dalam menjalankan keber-Islam-an tidak lepas dari aspek "kebaruan" yang melekat dalam Islam moderat atau Wasathiyah itu sendiri. Khazanah fikih, teologi, maupun kalam nyaris tidak menyentuh terminologi tersebut. Sentuhan khazanah tafsir yang ditemukan, lebih karena terhadap ayatayat tentang wasathiyah, sehingga dengan sendirinya para mufassir akan memberikan ulasannya. Penting dicatat bahwa, Islam wasathiyah sendiri hadir sebagai kelanjutan dari Islam moderat yang oleh sebagian kalangan muslim ditolaknya, karena bercorak barat. Dari sini, muncul usaha serius untuk menemukan nomenklatur genuine dari sumber otentik Islam, sehingga munculnya diskursus wasathiyah, qisth, qashdu, adālah, dan seterusnya.

\section{Profil Pesantren dan Madrasah Diniyah Darussalam}

Keberadaan Madrasah Diniyah Darussalam secara historis tidak dapat dilepaskan dari berdirinya Pondok Pesantren Darussalam Keputih dan YAPITA Surabaya. Berdirinya pesantren sendiri melewati proses yang cukup panjang dari generasi pertama hingga perkembangannya saat ini. Dikenal dengan nama $\mathrm{KH}$ Nur Fadhil atau yang populer dengan Yai Nur Fadhil; Habib, meskipun, bukan dari generasi yang mendirikan pesantren, namun ia memiliki peran historis yang sangat penting dalam pendiriannya.

Yai Nur Fadhil hanyalah seorang petani biasa, namun memiliki pengetahuan mendalam dalam bidang keagamaan Islam. Dengan dukungan istrinya yang bernama Nyai Muzayyanah, ia tergerak untuk memberikan pengetahuan yang dimilikinya kepada masyarakat sekitar, terutama anak-anak yang saat itu dipahami jauh dari pola kehidupan yang Islami. Untuk merealisasikannya, ia kemudian mendirikan mushalla sangat sederhana dan menjadi embrio berdirinya madrasah Tarbiyatul Aulad, yang hingga kini masih tetap dipertahankan oleh penerusnya dan diberi nama Mushalla Nur Fadhil. 
Terdapat dua fungsi ganda musholla yang untuk masyarakat sekitar, sebagai tempat peribadatan dan sekaligus pembelajaran Islam. Pengakuan masyarakat terhadap kapasitas keilmuwan keagamaan Islam yang dimilikinya, menjadi pemicu semakin banyaknya anak-anak yang dipercayakan agar dididik oleh Yai Nur Fadhil. Dalam proses selanjutnya, jumlah anak-anak yang mengaji di mushalla semakin bertambah dan bukan hanya masyarakat sekitar, melainkan dari kawasan-kawasan yang cukup jauh dari Keputih.

Keberhasilan Yai Nur Fadhil dalam mendidik anak-anak masyarakat sekitar memunculkan desakan agar ia mendirikan lembaga pendidikan formal. Terhadap desakan masyarakat tersebut, bukan berarti Yai Nur Fadhil menolaknya, melainkan harus mempersiapkan terlebih dulu sarana maupun prasarananya. Selain itu, pendirian lembaga pendidikan formal juga membutuhkan perhatian yang lebih mendalam. Setelah melakukan persiapan yang matang, baru secara resmi didirikan lembaga pendidikan formal, Madrasah Ibtidaiyah Tarbiyatul Aulad yang pada akhirnya berubah bentuk menjadi Sekolah Dasar Tarbiyatul Aulad, dan selanjutnya terus berkembang dengan munculnya Taman Kanak-kanak Tarbiyatul Aulad, Sekolah Menengah Pertama (SMP) Tarbiyatul Aulad, dan disusul pembangunan Sekolah Menengah Umum (SMU) Tarbiyatul Aulad. Untuk memudahkan proses pengelolaan unit-unit lembaga pendidikan formal tersebut, maka dibentuklah yayasan dengan nama Yayasan Pendidikan Islam Tarbiyatul Aulad yang populer dengan akronim YAPITA., dan saat ini sekolah-sekolah tersebut lebih dikenal nama TK, SD, SMP, dan SMA YAPITA. ${ }^{24}$

Seiring dengan makin senjanya usia Yai Fadhil, ia mulai memikirkan estafet kepemimpinan, sehingga dipilih KH Ali bin Marzuki yang merupakan suami dari putri keduanya (Fatimah) untuk membantunya. Selain karena diyakini memiliki kapasitas yang dikehendaki Yai Fadhil, dipilihnya Yai Ali karena menantu pertamanya KH Ahmad bin Abdul Mukhith bin Ya'qub (suami Nyai Musyarofah) lebih memilih mengabdikan diri di pesantren keluarganya, tepatnya di Pesantren Siwalan Panji Sidoarjo, yang pada akhirnya menetap dan dimakamkan di lingkungan Masjid Agung Sunan Ampel, karena beliau juga menjadi salah satu Imam Besar di masjid tersebut. Yai Ahmad berdasarkan mata rantai hubungan keluarga merupakan keturunan langsung Syeikh Nawawi alBantani dari jalur ibunya yang bernama Nyai Zuhrah. Ibunya Yai Ahmad tersebut merupakan anak perempuan Syeikh Nawawi dari hasil perkawinannya yang kedua dengan Nyai Hamdanah.

${ }^{24}$ Tentang Yapita dan kelembagaan formal yang berada di bawah naungannya, dapat dirujuk pada Zumrotul Mukaffa, "Existentialism in the Development of Islamic Education Institutions: A Portrait of Excellent School Development of Yapita Primary School Surabaya", Dinamika Ilmu, Vol. 17 No. 2 (2017), 309-330. 
Pengelolaan madrasah menjadi tanggung jawab sepenuhnya Yai Ali, pasca wafatnya Yai Fadhil pada tahun 1959. Pesatnya perkembangan lembaga pendidikan formal yang dikelolanya dan ditambah usia yang makin mendekati senja, Yai Ali membutuhkan figur yang dapat membantu dan sekaligus akan meneruskan estafet kepemimpinannya. Atas dasar itu, ia kemudian memanggil KH Abdus Syakur dan KH Hasyim Rawi untuk lebih berperan dalam pengelolaan lembaga pendidikan dibawah naungan YAPITA. Yai Syakur merupakan menantu dari Yai Ahmad (menantu pertama Yai Nur Fadhil), sedangkan Yai Rowi adalah menantu Yai Ali sendiri. Yai Syakur dan Yai Hasyim pada akhirnya menjadi pengelola YAPITA setelah wafatnya Yai Ali.

Pesatnya perkembangan lembaga pendidikan yang berada dibawah naungan YAPITA membuat seluruh energi sumber daya manusia nyaris terkonsentrasi untuk mengurusnya. Konsekuensinya, pengajian rutin dengan sistem bandongan yang sebelumnya telah dirintis oleh Yai Nur Fadhil menjadi sedikit terabaikan, meskipun tidak sampai vakum. Fenomena tersebut direspon oleh Yai Syukur dengan kembali menggerakkan sistem dakwah kultural yang salah satunya adalah, menjaga kontinuitas pengajian dengan sistem sorogan dan dikelola secara lebih intent. Tidak hanya itu, Yai Syakur juga merintis kegiatan dakwah kultural lainnya dalam bentuk istighatsah reguler setiap malam Selasa. Kegiatan ini diikuti bukan saja oleh masyarakat sekitar, melainkan juga dari luar Keputih. Dalam menjalankan keseluruhan aktifitas dakwah kulturalnya ini, Yai Syakur mendapat dukungan sepenuhnya dari Nyai Zuhrah yang secara genealogis merupakan cicit dari Syeikh Nawawi al-Bantani dari jalur neneknya dengan nama yang sama Nyai Zuhrah, Ibunda KH. Ahmad bin Muhith, menantu pertama KH. Nur Fadlil.

Beberapa segmen masyarakat seperti masyarakat awam sekitar Keputih dan anak-anak usia produktif sudah terwadahi dalam kerangka dakwah kultural Yai Syakur. Ia kemudian menggagas untuk mendirikan pesantren yang menerima santri berlatar belakang mahasiswa. Gagasan tersebut muncul seiring dengan semakin banyaknya kampus-kampus yang berdiri dan lokasinya berdampingan dengan YAPITA. Sebagai realisasinya, tepatnya pada tahun 2006, berdirilah pesantren yang diberi nama Pondok Pesantren Darussalam. Agar pengelolaan pesantren lebih efektif, maka pengelolaannya dipisahkan dari YAPITA, meskipun masih dalam lingkup satu keluarga besar.

Pada awal perintisannya, manajemen pesantren masih sangat sederhana dengan menempatkan Yai Syakur sebagai pengambil keputusan sepenuhnya, para santri tidak tinggal di asrama, mereka hadir hanya untuk mengaji kitab kuning, lalu kembali ke tempat tinggal masing-masing. Seiring dengan telah selesainya masa studi putera-puteri Yai Syakur baik dari pesantren maupun 
perguruan tinggi, manajemen dan pengembangan sarana maupun prasarananya mulai dikembangkan secara terencana. Sejak tahun 2012, pesantren mengembangkan gedung asrama santri menjadi tiga lantai dan beberapa ruangan kelas untuk kegiatan belajar-mengajar santri. Ditengah proses pengembangan berlangsung, tepatnya tanggal 1 April 2014, KH Abdus Syakur wafat dan estafet kepemimpinan dilanjutkan secara kolektif-kolegial oleh putera-puterinya. Untuk memudahkan mekanisme penataan managerial berdasarkan sistem modern, maka pada 1 April 2015, kelembagaan pesantren dilegalkan menjadi Yayasan Pondok Pesantren Darussalam

Dalam kelembagaannya yang lebih modern saat ini, pesantren memiliki visi "Menjadi sumber pencerahan bagi tercapainya sumber daya manusia yang bermanfaat bagi agama, bangsa dan Negara". Visi tersebut diturunkan menjadi beberapa misi, sebagai berikut: “1) Penanaman keimanan, ketaqwaan kepada Allah dan pembinaan akhlak mulia; 2) Menghasilkan sumber daya muslim yang mengusai ilmu pengetahuan keislaman multikultur berhaluan Islam Alussunah wal Jamaah An-Nahdhiyyah; 3) Menjadi fasilitator bagi berkembangnya Ilmu Pengetahuan dan Teknologi (IPTEK); 4) Menghasilkan sumber daya nasionalis yang berkomitmen mangamalkan dan memajukan nilai-nilai Islam di dalam berbangsa dan bernegara; dan 5) Mengembangkan unit-unit usaha produktif guna meningkatkan kemakmuran dan kesejahteraan masyarakat, baik yang bersifat material maupun spiritual. Dari visi pesantren diketahui dengan pasti bahwa, sejak awal pesantren bercorak moderat, seperti yang dikembangkan oleh organisasi Islam Nahdhatul Ulama (NU).

Lokasinya yang sangat berdekatan dengan kampus ITS, pesantren Darussalam ini lebih banyak dihuni oleh para mahasiswa ITS. Semula mahasiswa yang tinggal di pesantren ini hanya belasan, dalam perkembangannya, kehadiran pesantren mendapat apresiasi positif dari mahasiswa baru dari kampus-kampus selain ITS. Mereka akhirnya berdatangan dan menjadi bagian dari santri Pesantren Darussalam. Mereka berasal dari Politeknik Elektronika Negeri Suarabaya (PENS), Politeknik Perkapalan Negeri Surabaya (PPNS), Universitas Airlangga (Unair), Institut Teknologi Adhi Tama (ITAT) Surabaya, Universitas Narotama, dan Universitas Hang Tuah. Secara keseluruhan jumlah santrimahasiswa non-ITS sebanyak 80 santri. Keberadaan mereka di pesantren tidak berada dalam kawasan yang eksklusif, melainkan berbaur dengan masyarakat sekitar, terutama yang mengikuti kegiatan pengajian reguler maupun istighatsah.

Berdasarkan data pesantren, jumlah pendaftar dari kalangan mahasiswa di pesantren Darussalam dari tahun ke tahun terus mengalami peningkatan. Hanya saja, keterbatasan sarana dan prasarana yang dimiliki membuat pengelola membatasi kuota penerimaan santri. Pertimbangan keterbatasan itu pula yang 
melatari munculnya keputusan hanya menerima mahasiswa putra sebagai santri. Padahal, peminat dari mahasiswa perempuan juga cukup signifikan dari tahun ke tahun.

\section{Madrasah Diniyah dan Moderatisme Islam}

Sulit membantah bahwa, kehadiran pesantren mahasiwa menjadi sangat penting di tengah kuatnya arus radikalisasi Islam di kampus. Secara kelembagaan, keberadaannya memiliki peran penting untuk secara langsung mengimplementasikan gagasan deradikalisasi Islam di kalangan santri yang sekaligus berstatus sebagai mahasiswa. Pesantren Darussalam Keputih Surabaya dapat disebut sebagai salah satu pesantren mahasiswa yang terlibat langsung dengan mentransformasikan tata nilai Islam moderat sebagai counter-discourse terhadap doktrin dan ideologi Islam trans-nasional.

Gagasan transformasi Islam moderat di pesantren melalui Madrasah Diniyah mulai menjadi perhatian serius, seiring menguatnya diskursus radikalisasi Islam, terutama di ITS yang diterima oleh pengelola pesantren pada tahun 2015. Dalam bentuk praksisnya, pengelola pesantren mulai dirumuskan reorientasi pembelajaran bagi santri-mahasiswa. Bagi pesantren, potensi masuknya radikalisasi kepada para santri-mahasiswa sangat tinggi, sehingga sikap pembiaran dan apatis pengelola dapat berakibat fatal. Jika terdapat santrimahasiswa yang terpapar akan membuka kemungkinan terjadinya transformasi radikalisasi di lingkungan pesantren. Mereka akan menjadikan komunitas sekitar pesantren sebagai target radikalisasi secara diam-diam tanpa terkontrol oleh pengelola pesantren. Pada saat yang sama, keberadaan santri-mahasiswa yang berpotensi terpapar radikalisasi Islam juga menjadi tantangan tersendiri bagi pesantren untuk lebih memiliki peran pentingnya. Pesantren dapat menjadi struktur mediasi untuk menyediakan wacana tanding terhadap doktrin maupun ideologi yang telah diperoleh melalui proyek radikalisasi Islam di kampus.

Merespon terhadap fenomena di atas, pesantren melakukan revitalisasi terhadap sistem pembelajaran Madrasah Diniyah Takmiliyah. Di Darussalam, Madrasah Diniyah terbagi kedalam Kelas Awwaliyah untuk kelas dasar, Kelas Wustha I, II dan III bagi kelas lanjutan, dan Kelas Ulya I, II, dan III untuk kelas tinggi. Kegiatan pembelajaran berlangsung setelah shalat Ashar (Kelas Awwaliyah) dan setelah Subuh, dan setelah Isya' untuk kelas lanjutan, baik Wustha maupun Ulya. Seluruh santri-Mahasiswa merupakan santri Madrasah Takmiliyah Ulya dan dengan demikian, pembelajarannya berlangsung setelah dan sebelum perkuliahan di kampus berlangsung.

Berbeda dengan Madrasah Diniyah yang dikembangkan oleh pesantrenpesantren pada umumnya, pesantren Darussalam menggunakan model penjurusan untuk setiap santrinya. Santri Madrasah Diniyah tingkat Ulya 
dikelompokkan menjadi tiga jurusan, yaitu: Jurusan Tahfiz al-Qur'an, Jurusan Bahasa, dan Jurusan Fikih. Setiap santri baru diberikan formulir untuk memilih salah satu dari ketiga jurusan tersebut. Bagi santri yang bermaksud menghafal alQur'an yang telah menjadi bagian dari program pesantren, maka disarankan untuk memperkuat basis keilmuwannya dengan memasuki Madrasah Diniyah program tahfidz, sementara yang hendak memperdalam bahasa Arab disarankan masuk program Bahasa, dan pendalaman terhadap hukum Islam memasuki program Fikih.

Pada dasarnya, masing-masing jurusan tetap menggunakan rujukan kitab yang sama sebagai bahan ajar. Untuk tingkat Ulya, kitab-kitab yang diajarkan antara lain: 1) Al-Qur'an al-Karim; 2) Matan Arba'in al-Nawawi; 3) Syarakh Arba'in al-Nawawi; 4) Tuhfah al-Qārin; 4) Fath al-Karīm al-Mannān; 5) al-Jazāriyah; 6) Bidāyah al-Hidāyah; 7) Nashā'ih al-Ibād; 8) Akhlāq al-Qur'ān; 9) Ta'Tim alMutā'alim; 10) Fath al-Qarīb; 11) Risālah Ahl al-Sunnah wa al-Jamāah; 12) AlJurümiyah; 13) Amtsilah al-Tashrifiyah; 14) Al-Muhāwarah al-Haditsah; 15) Fiqih Sosial; 16) Mabādi' Awaliyah; dan al-Sullam fì Ushūl al-Fiqh. Seluruh kitab-kitab tersebut diajarkan kepada seluruh santri dari tiga jurusan. Hanya saja, keluasan dan kedalaman pembahasan masing-masing kitab tergantung pada jurusan yang dipilih santri (lihat struktur mata kajian \& jadual kajian berikut pada tabel 2 \& 3).

Dalam tabel jadual di atas digambarkan, mata pelajaran dibagi menjadi dua kategori, yaitu: mata pelajaran yang berstatus dasar umum, mata pelajaran wajib, dan keahlian. Mata pelajaran dasar umum sendiri terbagai menjadi dua kategori, intra-kurikuler dan ekstra-kurikuler. Mata pelajaran dasar umum kategori intrakurikuler disampaikan secara klasikal dengan jadual yang berbeda antar jurusan. Terdapat empat mata pelajaran dalam kategori ini, yaitu: Aswaja, Fikih, Akhlaq, dan Akhlak-Tasawuf. Mata pelajaran yang pertama lebih diorientasikan pada pembentukan kharakter yang digali dari etika Islam, sedangkan kedua berorientasi pada penguasaan terhadap doktrin-doktrin tasawuf sunni-amali. Sedangkan yang berkategori intra-kurikuler disampaikan secara bersamaan di luar ruang kelas, yaitu: di ruang pertemuan Pesantren Darussalam yang dikemas dalam nomenklatur Majelis Ilmi. Terdapat lima bidang kajian yang menjadi pembahasan dalam Majelis Ilmi, yaitu: 1) Pendidikan Karakter; 2) Arsitektur Islam; 3) Tafsir Tematik Al-Qur'an; 4) Fikih Lingkungan; dan 5) Islamic Enterpreneurship.

Untuk mata pelajaran keahlian sangat tergantung pada jurusan yang dipilih santri. Bagi santri jurusan Tahfidz, mata pelajaran keahlian meliputi: 1) Sema'an Tahfidz; 2) Ulumul Qur'an; 3) Setoran Tahfidz; dan 4) Khataman dan Setoran Tahfidz. Sema'an Tahfidz adalah hampir sama dengan Khataman, yaitu: santri yang ditunjuk menyampaikan hafalannya dihadapan pengajar dan para 
santri lainnya. Sementara pengajar dan santri mendengarkan dengan seksama dan memberikan tanda, jika santri yang ditunjuk melakukan kesalahan hafalan agar ia membenarkannya dengan mengulang kembali. Hanya saja, proses hafalan tidak sampai mengkhatamkan seluruh isi al-Qur'an (30 Juz). Sebaliknya, khataman menunjuk pada proses hafalan al-Qur'an berdasarkan kemampuan hafalan santri yang pada akhirnya dapat mengkhatamkan seluruh isi al-Qur'an. Misalnya, santri yang baru menghafal Juz I, maka ia berkewajiban menyampaikan kemampuan hafalannya, begitu pula yang sudah memasuki Juz 15, dan begitu seterusnya hingga Juz 30 (Juz 'Amma). Sedangkan mata pelajaran Setoran bersifat wajib bagi setiap para santri yang artinya, setiap santri wajib untuk mendemonstrasikan hafalannya dihadapan pengajar untuk dilakukan penilaian. Jika dianggap sudah memenuhi syarat, maka santri tersebut dapat melanjutkan hafalannya ke Surah atau Juz berikutnya.

Pada program Bahasa, santri diharuskan lebih menguasai gramatika Bahasa Arab, baik Nahwu maupun Sharaf. Masing-masing mata pelajaran ini diajarkan dua kali pertemuan dalam satu pekan efektif. Selama dua pertemuan untuk masing-masing mata pelajaran tersebut, santri diharuskan mampu menghafal dan memahami kandung teks tentang teori-teori gramatika Bahasa Arab. Kemampuan menghafal dan memahami diaplikasikan secara terpisah dan mendalam pada mata pelajaran tersendiri, yaitu mata pelajaran Bahasa Arab.

Sedangkan dalam Program Fikih lebih banyak mendalami bidang-bidang kajian hukum Islam berdasarkan kitab rujukan yang digunakan. Untuk program ini, mata pelajaran fikih diajarkan selama dua kali dalam satu pekan. Untuk memperkuat kemampuan penalaran santri di bidang fikih tersebut, mereka disyaratkan juga harus menguasai mata pelajaran Ushul Fikih sebagai mata pelajaran pendukungnya. Sebagaimana terlihat dalam jadual, mata pelajaran ini tidak diajarkan kepada santri dari jurusan Tahfidz dan Bahasa. Sama halnya dengan Sema'an, Setoran, dan Khataman, sebagai tiga mata pelajaran keahlian dalam program Tahfidz yang tidak diajarkan dalam program Fikih maupun Bahasa.

Untuk menambah kemampuan berkomunikasi santri dengan masyarakat sekitar dan kemampuannya untuk menjalankan dakwah, maka pesantren menyelenggarakan program kegiatan tadrïb al-khitäbah (latihan berpidato). Kegiatan ini dilaksanakan pada setiap malam Ahad (Minggu) setelah shalat Isya' yang diikuti seluruh santri, dewan pengajar, dan perwakilan dari pengasuh.

Pesantren juga menyelenggarakan program Napak Tilas untuk mendukung pencapaian hasil belajar para santri Madrasah Diniyah, terutama dalam mata pelajaran Akhlak-Tasawuf. Napak Tilas merupakan program untuk mengunjungi makam-makam para wali maupun tokoh sufi ternama di tanah air. 
Selain untuk memperkenalkan dan merefleksikan gagasan-gagasan yang telah ditransformasikan oleh para wali tersebut, kegiatan Napak Tilas juga dimaksudkan untuk menggugah kesadaran dan wawasan para santri. Bahwa, penyebaran Islam dengan menggunakan pendekatan Islam moderat berhasil mengislamkan, bukan saja lingkungan para wali tersebut, melainkan Jawa dan bahkan Nusantara.

Revitalisasi model pembelajaran yang berbasiskan pada tata nilai Islam moderat dilakukan dengan tetap mempertahankan kitab-kitab yang dijadikan rujukan, terutama bidang hukum Islam (fikih). Hanya saja, metode pembelajarannya tidak lagi sepenuhnya menggunakan sistem bandongan, melainkan perpaduan antara bandongan dan diskusi (muhāwarah). Pada tahapan pertama, pengajar membacakan kata demi kata dalam teks berbahasa Arab dengan memberikan makna berbahasa Jawa-pegon, dan seluruh santri dalam satu kelas mencatatnya kedalam kitabnya masing-masing (bi al-ma'nā allughawi). Tahapan kedua, pengajar memberikan penjelasan tentang kandungan teks secara apa adanya (bi al-ma'nā al-murād). Tahapan ketiga, guru memberikan penjelasan dengan pendekatan teks-konteks untuk memahami teks yang sedang di kaji (bi al-ma'nā al-waqi'i). Tahapan keempat, guru memfasilitasi santri untuk mendiskusikan dan berfikir kritis untuk mendialogkan antara kandungan teks dan konteks (al-istifkār wa al-tawāzun baina al-nash wa al-wāqi').

Satu contoh, misalnya, pembahasan tentang hukum pidana (al-jināyah) sebagaimana tercantum pada Kitāb Ahkām al-Jināyāt (Pembahasan tentang Hukum-Hukum Pidana Islam), sebagaimana terdapat dalam kitab Fath al-Qarib. Kitab ini merupakan kitab fikih yang menjadi teks wajib bagi santri Madrasah Takmiliyah Ulya. Salah satu pokok bahasan didalamnya adalah hukuman bagi pelaku pembunuhan yang disengaja (al-'amd al-mahdl). ${ }^{25}$

Pada tahapan pembelajaran bi al-ma'nā al-lughawi, maka guru menjelaskan arti kata demi kata (mufradāt) yang didalamnya dengan pemaknaan Jawa-pegon (lihat ilustrasi di bawah).

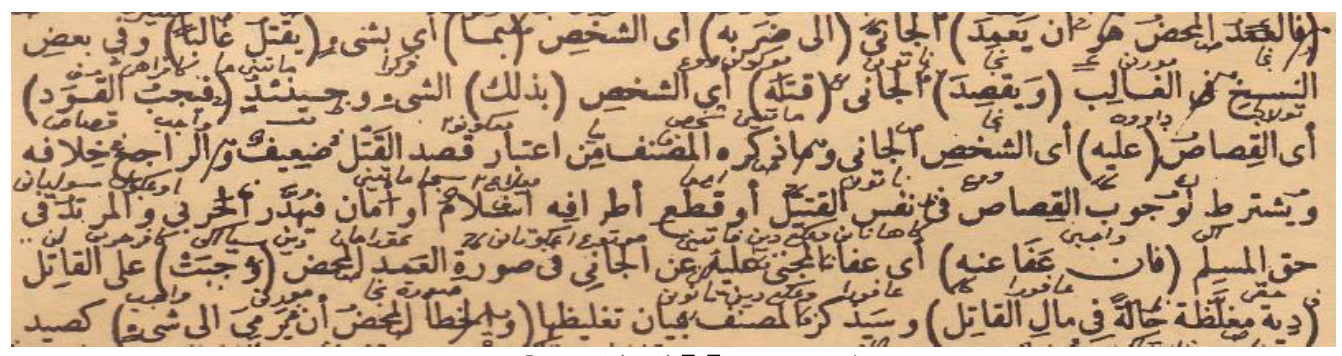

Sumber: Al-Ghāzĩ: 1343: 53.

${ }^{25}$ Muhamamd Ibnu Qāsim al-Ghāzi, Fath al-Qarīb al-Mujīb, (Semarang: Ma'had al-Islamī alSalafi, 1343 H). 53. 
Berdasarkan ilustrasi di atas, pengajar mengartikan masing-masing kata dalam teks berikut memberikan simbol kedudukan kata berdasarkan kaidah tata bahasa Arab yang berlaku, misalnya, "fa al-'amd" (mangka utawi nejo mateni), "almahdlu" (kang murni), dan seterusnya. Pemaknaan secara lughawi> menjadi penting agar santri terbiasa memahami teks-teks fikih berbahasa Arab kata demi kata, sehingga ia dapat menggunakan kemampuannya tersebut untuk mendalami teks-teks lain dalam bidang yang sama.

Tahapan pembelajaran bi al-ma'nā al-murād, maka pengajar memberikan penjelasan atas maksud narasi di atas. Bahwa, pembunuhan yang disengaja adalah peristiwa yang seseorang atau pelaku dengan sengaja memukul seseorang dengan sesuatu yang lazimnya dapat mengakibatkan terbunuhnya seseorang. Maka bagi pelakunya wajib hukumam qishash. Jika anggota keluarga korban memberikan pengampunan, maka bagi pelaku wajib menggantinya dengan materi dalam jumlah besar dari harta bendanya sendiri tanpa ada penundaan. Berapa ukuran pengganti yang harus dibayarkan akan dijelaskan dalam pembahasan selanjutnya.

Tahapan pembelajaran bi al-ma'nā al-waqì'i adalah mendikusikan pembunuhan dalam konteks hukum positif di tanah air. Pengajar memfasilitasi dengan membuka pertanyaan, misalnya, apakah pembunuhan yang disengaja memiliki kesamaan dengan pembunuhan berencana. Demikian pula, apakah hukuman bagi pelaku pembunuhan yang disengaja sama dengan hukuman berencana. Pembelajaran ini untuk membiasakan santri berfikir mendalam tentang kesamaan dan perbedaan secara substantif bukan formal-normatif antara fikih dan hukum positif.

Pada tahapan terakhir yaitu pembelajaran dengan al-istifkār wa altawāzun baina al-nash wa al-wāqi', menunjuk pada proses pengkajian secara kritis untuk mendialogkan teks dan konteks yang lebih luas, yaitu: hukum positif, Islam moderat, dan doktrin hukum pidana gerakan Islam trans-nasional, misalnya, HTI. Beberapa pertanyaan dapat diajukan kepada santri untuk memulai pengkajian; 1) Bagaimana perspektif hukum pidana pembunuhan menurut fikih yang direpresentasikan oleh Kitab Fath al-Qarib?; 2) Bagaimana doktrin pidana pembunuhan menurut HTI?; 3) Bagaimana Islam moderat memberikan jawaban atas hukum pidana pembunuhan tersebut?; 4) Secara substantif, apakah sistem pidana pembunuhan dalam hukum positif bertentangan dengan Fath al-Qarīb, Islam Moderat, dan HTI?

Untuk mendapatkan jawaban mendalam, pengajar memfasilitasi para santri untuk melacak sistem pidana Islam yang dirumuskan HTI. Dalam sistem khilafah Islamiyah, hukum pidana yang digunakan adalah pidana Islam yang diakui kredibilitasnya secara kelembagaan. Konsekuensinya, pengajar harus 
menemukan referensi yang digunakan oleh HTI, yaitu: Nidzām al-Uqubāt karangan Abdurrahman al-Maliki. ${ }^{26}$ Pada saat yang sama, untuk menemukan perspektif dari Islam moderat, guru menghubungkan santri dengan website WIKI ASWAJA dan ASWAJA NU yang dikelola oleh Pusat Kajian Aswaja PWNU Jawa Timur untuk mendapatkan hasil-hasil bahts al-masā'il terkait dengan pokok bahasan tersebut.

Proses selanjutnya adalah, mencari titik persamaan dan perbedaan antara ketiga rujukan dimaksud. Jika ditelusuri, konstruksi doktrinal pidana pembunuhan dalam perspektif HTI yang direpresentasikan oleh al-Maliki> tidak jauh berbeda dengan kandungan teks-teks fikih. ${ }^{27}$ Pada tahap selanjutnya, menelusuri perspektif yang dibangun oleh pengelola website WIKI ASWAJA dan ASWAJA NU. Jika tidak ditemukan, maka diambil jalan keluar melalui implementasi tata nilai yang diusung oleh Pusat Kajian Aswaja PWNU Jawa Timur, yaitu: mengambil jalan tengah (tawassuth), mempertimbangkan argumentasi tekstual dan rasional (tawazun), dan tranformasi nilai-nilai keadilan dan kemanusiaan (al-adālah).

Revitalisasi pembelajaran dengan menggunakan model di atas akan mengarahkan santri untuk tidak berfikir monolitik bahwa, khilafah Islamiyah sebagai satu-satu sistem pemerintahan yang paling kredibel dan otoritatif. Hukum pidana pembunuhan yang bersumber pada hukum positif dalam bingkai Sistem Negara Kesatuan Republik Indonesia (NKRI) secara kasat mata memang bertentangan dengan hukum fikih maupun sistem pidana Islam yang dikembangkan oleh HTI. Namun, perbedaan tersebut bukan berarti berkonsekuensi pada penggantian sistem NKRI menjadi sistem Khilafah Islamiyah. Kekurangan hukum positif sangat mungkin terjadi, karena ia adalah produk manusia yang dibatasi oleh ruang dan waktu. Pembaharuan hukum positif, termasuk pidana pembunuhan, sangat terbuka dilakukan dengan tanpa harus merubah NKRI. Dari sini, santri banyak belajar tentang toleransi terhadap perbedaan dan kemajemukan doktrin hukum pidana dalam Islam yang tidak mungkin disatukan dalam bingkai Khilafah Islamiyah.

\section{E. Kesimpulan}

Berbagai paparan di atas memberikan petunjuk penting bahwa, Madrasah Diniyah Takmiliyah Darussalam yang berada di bawah naungan Yayasan Pondok Pesantren Darussalam memiliki peran penting ditengah maraknya radikalisasi Islam di kampus PTU. Keberadaan pesantren mampu menjadi struktur atau

${ }^{26}$ Abdurrahman al-Māiliki, Nidzām al-Uqubāt, (Beirut: Dar al Ummah, 1994).

${ }^{27}$ Lihat pembahasan tentang al-qatl al- 'amd dan 'uqubah qatl al-amd halaman 46-47 dalam Nidzām al-Uqubāt. 
institusi mediasi untuk mentransformasikan Islam moderat di kalangan santrimahasiswa. Nilai-nilai maupun doktrin-doktrin keagamaan Islam moderat diharapkan menjadi wacana tanding (counter discourse) terhadap doktrin dan ideologi gerakan Islam trans-nasional yang ditawarkan melalui program radikalisasi Islam di kampus-kampus PTU, termasuk Institut Teknologi Sepuluh November (ITS) Surabaya.

Dalam bentuk kongkritnya, pesantren melakukan revitalisasi sistem pembelajaran Madrasah Diniyah Takmiliyah Ulya. Pertimbangannya, seluruh santri-mahasiswa merupakan santri di Madrasah Diniyah jenjang Ulya tersebut. Revitalisasi tidak berarti memberangus model pembelajaran yang lama menjadi sama sekali, namun tetap mempertahankan sistem yang lama dengan modifikasi pada aspek proses pelaksanaannya. Terutama bidang kajian fikih siyāsah dan jināyah yang banyak menjadi perhatian gerakan Islam trans-nasional, model pembelajaran menggunakan sistem perpaduan antara sorogan-muhāwarah.

Terdapat empat tahapan yang ditempuh dalam pelaksanaan pembelajaran. Pertama, proses memberikan pemahaman kata demi kata yang ada dalam teks-teks fikih rujukan dan respon santri-mahasiswa adalah memberikan catatan dengan jawa-pegon di kitabnya masing-masing. Proses ini disebut juga dengan pembelajaran untuk memberi makna secara literal (bi alma'nā al-lughawi). Kedua, pengajar melakukan eksplanasi kandungan berdasarkan teks yang ada, tanpa menambah sumber rujukan lain. Proses ini dapat disebut sebagai pembelajaran yang berorientasi pada pemahaman apa adanya terhadap kandungan teks (bi al-ma'nā al-murād). Ketiga, pengajar memfasilitasi santri untuk mendapatkan pemahaman bi al-ma'nā al-waqìi $i$ Yaitu, pemahaman dengan menggunakan pendekatan teks-konteks untuk memahami teks yang sedang di kaji. Keempat, proses belajar-mengajar al-istifkār wa altawāzun baina al-nash wa al-wāqi'. Artinya, proses yang mampu memfasilitasi santri guna mendiskusikan dan berfikir kritis untuk mendialogkan antara kandungan teks dan konteks. Konteks yang dimaksud adalah, kandungan teks yang sedang di kaji dan mengaitkannya dengan realitas hukum yang berlaku di tanah air, rujukan yang dikembangkan oleh gerakan Islam moderat, dan gerakan Islam trans-nasional yang digali dari website WIKI ASWAJA dan ASWAJA NU. Namun, jika dalam kedua situs resmi tersebut tidak ditemukan rujukan, maka pengajar memfasilitasi untuk mengimplementasikan prinsip tawassuth, tawāzun, dan adālah untuk memahami kandungan teks yang dikaji.

Dampak yang diharapkan dari revitalisasisi model pembelajaran ini adalah, santri akan memiliki ketrampilan berfikir kompleks yang tidak lagi monolitik dengan meyakini bahwa, sistem khilafah berikut aspek-aspek yang didalamnya memiliki kebenaran absholut. Bagaimanapun, doktrin yang 
dikembangkan dan terumuskan dalam teks-teks resmi gerakan Islam transnasional merupakan produk ijtihad manusia yang berkemungkinan benar dan salah. Pada saat yang sama, model sorogan-muhāwah yang termanifestasi kedalam empat tahapan juga diharapkan membangun daya kritis santri-mahasiswa terhadap kandungan teks-teks keagamaan yang dikajinya selama ini, termasuk pula terhadap konstruksi sistem NKRI dengan berbagai aspek didalamnya. Sikap kritis bukan dimaksudkan untuk mengganti sistem yang ada, melainkan menemukan kemungkinkan transformasi substansi dan bukan formal-normatif Islam kedalam aspek-aspek yang menjadi bagian dari NKRI tersebut.

\section{F. Referensi}

al-Ghāzi, Muhamamd Ibnu Qāsim. Fath al-Qarīb al-Mujīb. Semarang: Ma'had alIslami al-Salafi, $1343 \mathrm{H}$.

al-Mālikì, Abdurrahman. Nidzām al-Uqubāt. Beirut: Dar al Ummah, 1994.

Amin, Ma'ruf. "Paradigma Islam Wasathiyah, Ruh Gerakan MUI Semua Tingkatan." Mimbar Ulama, Majelis Ulama Indonesia, 2016: 11.

Angel Rabasa, Stacie L. Pettyjohn, Jeremy J. Ghez, and Christopher Boucek.

Deradicalizing Islamist Extremists. Santa Monica: The RAND Corporation, 2010.

Bowen, J.R. "Beyond Migration: Islam as a Transnational Public Space." Journal of Ethnic and Migration Studies, 2004: 1-14.

Burhani, Ahmad Najib. "The Banning of Hizbut Tahrir and the Consolidation of Democracy in Indonesia." ISEAS Perspective, 2017: 1-10.

Faizal, Achmad. KOMPAS.com. Mei 08, 2018.

https://regional.kompas.com/read/2018/05/08/17193701/dosen-its-sayabukan-hti-saya-tidak-punya-kepentingan-dengan-hti (accessed Agustus 24, 2018).

Hilmi, Danial. "Mengurai Islam Moderat sebagai Agen Rahmatan Lil 'Alamin." In Islam Moderat, Konsepsi, dan Aksi, by M. Zainuddin dan Muhammad In'am Esha dkk, 62. Malang: UIN Maliki Press, 2016.

Indonesia, Majelis Ulama. "Taujihat Surabaya, Islam Wasathiyah untuk Indonesia dan Dunia yang Berkeadilan dan Berkeadaban." Mimbar Ulama, Majelis Ulama Indonesia, 2016: 15.

Jakarta, PPIM UIN. Pemberdayaan Islam Moderat dalam Konteks Hubungan Luar Negeri. Jakarta: Pusat Pengkajian Islam dan Masyarakat (PPIM) Universitas Islam Negeri (UIN) Jakarta-Badan Pengkajian dan Pengembangan Kebijakan Departemen Luar Negeri, 2006. 
Kartini, Indriana. "Hizbut Tahrir Indonesia and the Idea of Restoring Islamic Caliphate." Masyarakat Indonesia, 2015: 1-14.

Kraince, Richard G. "The Role of Islamic Student Groups in the Reformasi Struggle: KAMMI (Kesatuan Aksi Mahasiswa Muslim Indonesia." Studia Islamika, 2000: 3-50.

Kurniawati, Rezki Alvionitasari dan Endri. TEMPO.CO. Mei 17, 2018. https://nasional.tempo.co/read/1089969/peledak-bom-di-surabaya-punyagen-teroris-siapa (accessed Agustus 24, 2018).

Leonard, Karen. "Transnational and Cosmopolitan Forms of Islam in the West." Harvard Middle Eastern and Islamic Review, 2009: 176-199.

Machmudi, Yon. "The Emergence of New Santri in Indonesia." Journal of Indonesian Islam, 2008: 69-102.

Mufid, Ahmad Syafi'i. Perkembangan Paham Keagamaan Transnasional di Indonesia. Jakarta: Badan Litbang dan Diklat Kementerian Agama RI, 2011.

Muhammad, Yusuf. DUTAISLAM.com. Mei 08, 2018.

http://www.dutaislam.com/2018/05/menghawatirkan-viral-tokoh-hti-kampusits-mulai-dosen-kaprodi-hingga-guru-besar.html (accessed Agustus 24, 2018).

Muhtadi, Burhanuddin. "The Quest for Hizbut Tahrir in Indonesia." Asian Journal of Social Science, 2009: 623-645.

Mukaffa, Zumrotul. "Existentialism in the Development of Islamic Education Institutions: A Portrait of Excellent School Development of Yapita Primary School Surabaya." Dinamika Ilmu, 2017: 309-330.

Njoto-Feillard, Gwenaël. Hizbut Tahrir Indonesia in 2014: The Political Economy of Discontent. Singapore: The ISEAS-Yusof Ishak Institute, 2015.

Radli, Muhammad Muhsin. Hizb al-Tahr>r, Tsaqa $>$ fatuhu wa Manha>juhu fi> Iqa>mah al-Daulah al-Khila>fah al-Isla>miyah. Baghdad: Kuliyah alUshu>luddi>n-al-Ja>mi'ah al-Isla>miyah, 2006.

Rinanda, Hilda Meilisa. detiknews. Mei 08, 2018. https://news.detik.com/jawatimur/4010598/viral-4-dosen-di-surabaya-tolakpembubaran-hti (accessed Agustus 24, 2018).

Siraj, Said Aqiel. Ahlusunnah wal Jama'ah Dalam Lintasan Sejarah. Yogyakarta: Penerbit LKPSM, 1997.

Suharto, Toto. "Gagasan Pendidikan Muhammadiyah dan NU sebagai Potret Pendidikan Islam Moderat di Indonesia." Islamica: Jurnal Studi Keislaman, 2014: 81-109. 
Suharto, Toto. "Indonesianisasi Islam: Penguatan Islam Moderat dalam Lembaga Pendidikan di Indonesia." Al-Tahrir, 2017: 155-178.

Syamsuddin, Din. "Islam Wasathiyah, Solusi Jalan Tengah." Mimbar Ulama, Majelis Ulama Indonesia, 2016: 7.

Utomo, Deni Prastyo. detiknews. Mei 08, 2018. https://news.detik.com/beritajawa-timur/d-4010766/rektor-unair-dosen-yang-tolak-pembubaran-hti-sedangdiklarifikasi (accessed Agustus 24, 2018).

Wahid, Abdurrahman, ed. Ilusi Negara Islam, Ekspansi Gerakan Islam Transnasional di Indonesia. Jakarta: The Wahid Institute, 2009.

Zulkifli, Asep Muhamad Iqbal dan. "Islamic Fundamentalism, Nation-state and Global Citizenship: The Case of Hizb ut-Tahrir." Indonesian Journal of Islam and Muslim Societies, 2016: 35-61. 
Zumrotul Mukaffa

\section{Lampiran-lampiran}

STRUKTUR ORGANISASI

PONPES DARUSSALAM KEPUTIH SURABAYA

JAWA TIMUR

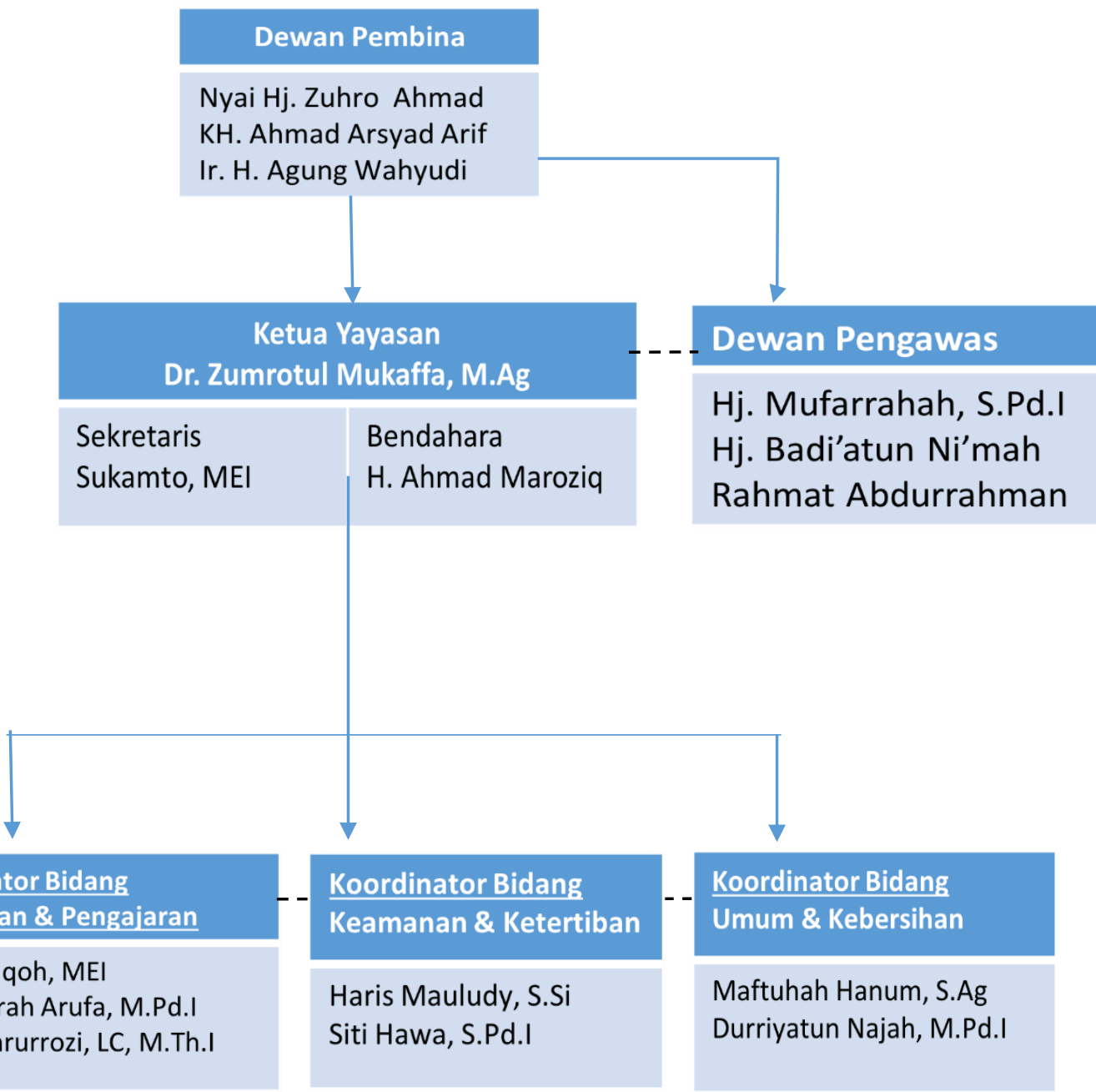

Koordinator Bidang

Pendidikan \& Pengajaran

Siti Musfiqoh, ME

M. Alfithrah Arufa, M.Pd.I

Moh. Fahrurrozi, LC, M.Th.I endahara

H. Ahmad Maroziq
Hj. Mufarrahah, S.Pd.

Hj. Badi'atun Ni'mah

Rahmat Abdurrahman
Koordinator Bidang

Umum \& Kebersihan

Maftuhah Hanum, S.Ag

Durriyatun Najah, M.Pd.I 
Tabel 1

Santri-Mahaiswa Pesantren Darussalam

Berdasarkan Data tahun 2018/2019

\begin{tabular}{|r|l|r|}
\hline \multicolumn{1}{|c|}{ No. } & Satuan Pendidikan Formal Yang Ditempuh & Jumlah \\
\hline 01 & Institut Teknologi Surabaya (ITS) & 44 \\
\hline 02 & Politeknik Elektronika Negeri Suarabaya (PENS) & 17 \\
\hline 03 & Politeknik Perkapalan Negeri Surabaya (PPNS) & 9 \\
\hline 04 & Universitas Airlangga (Unair) & 1 \\
\hline 05 & Institut Teknologi Adhi Tama Surabaya (ITAT) & 1 \\
\hline 06 & Universitas Narotama & 1 \\
\hline 07 & Universitas Hang Tuah & 81 \\
\hline 08 & SMA YAPITA & Jumlah \\
\hline
\end{tabular}

Sumber: Data Primer Pesantren (Diolah) 
Tabel 2

Struktur Kurikulum Madrasah Diniyah Takmiliyah

Tahun Kajian 2018/2019

\begin{tabular}{|c|c|c|c|c|}
\hline Tahun & Studi Alquran & Bahasa & Fiqh & Santri Baru 2018 \\
\hline \multirow[t]{2}{*}{ I } & $\begin{array}{l}\text { Tajwid (Al-Jazariyah) } \\
\text { Ulumul Quran (Fath AlKariim) } \\
\text { Fiqh (Takrib) } \\
\text { Hadits } \\
\text { Alquran Tahfidz }\end{array}$ & $\begin{array}{l}\text { Nahwu } \\
\text { Shorof } \\
\text { Bhs. Arab } \\
\text { Figh } \\
\text { Al-Quran }\end{array}$ & $\begin{array}{l}\text { Hadits } \\
\text { Fiqh } \\
\text { Bhs. Arab } \\
\text { Al-Quran } \\
\text { Ushul Fiqh } \\
\text { Bahtsul M. }\end{array}$ & $\begin{array}{l}\text { Akhlaq (Ta'lim) } \\
\text { Sejarah Islam } \\
\text { Indonesia } \\
\text { Al-Qur'an (Tafsir Munir) } \\
\text { Hadits (Tanqihul Qoul) } \\
\text { Pengenalan Pegon } \\
\text { Aswaja }\end{array}$ \\
\hline & \multicolumn{3}{|l|}{$\begin{array}{l}\text { Akhlaq Tasawuf Majelis IIm } \\
\text { Tarawih NU, Khusus: } 30 \mathrm{Juz} \text { ) Ta }\end{array}$} & $\begin{array}{l}\text { Majelis Ilmu Sabtu } \\
\text { Tahfidz * (Umum: Surat } \\
\text { Tarawih NU, Khusus: } 30 \\
\text { Juz) } \\
\text { Tahlil \& Yasiin } \\
\text { Tadarus Ba'da Maghrib }\end{array}$ \\
\hline \multirow{3}{*}{ II } & \multicolumn{2}{|l|}{ Dirosat Al-Qur'an } & Fiqh & \multirow[b]{2}{*}{$\begin{array}{l}\text { Fiqh (Bahjatul } \\
\text { Wasail) Sejarah Islam } \\
\text { Asia Tengah Al-Qur'an } \\
\text { Hadits (Bulughul } \\
\text { Marom \& Munir) } \\
\text { Nahwu Shorof }\end{array}$} \\
\hline & \multicolumn{2}{|c|}{$\begin{array}{l}\text { Ulumul Quran (Attibyan) } \\
\text { Figh (Fathul Qorib-lanjutan) } \\
\text { Nahwu (Mutammimah-lanjutan) } \\
\text { Shorof (Qowaidus shorfiyah-lanjutan) Bhs. } \\
\text { Arab (Al-Muhawaroh-lanjutan) Tafsir (Munir) }\end{array}$} & $\begin{array}{l}\text { Hadits (Bulughul } \\
\text { Marom) Fiqh } 1 \\
\text { (Fathul Muin) Bhs. } \\
\text { Arab } \\
\text { (Mahawaroh) Ushu } \\
\text { I Fiqh (Mabadiul } \\
\text { Awaliyah }\end{array}$ & \\
\hline & \multicolumn{3}{|c|}{$\begin{array}{l}\text { Aswaja } \\
\text { Akhlaq Tasawuf Majelis Ilmu Sabtu Tahfidz * (Umum: Surat } \\
\text { Tarawih NU, Khusus: } 30 \text { Juz) Tahlil \& Yasiin }\end{array}$} & $\begin{array}{l}\text { Majelis Ilmu } \\
\text { Sabtu Tahfidz* } \\
\text { (Umum: Juz 30, Khusus: } \\
30 \text { Juz) Tahlil \& } \\
\text { Yasiin Tadarus Ba'da } \\
\text { Maghrib }\end{array}$ \\
\hline \multirow{2}{*}{ III } & \multicolumn{2}{|l|}{ Dirosat Al-Qur'an } & Fiqh & \multirow{2}{*}{$\begin{array}{l}\text { Tasawuf (Bidayatul } \\
\text { Hidayah) Sejarah } \\
\text { Islam Timur } \\
\text { Tengah Al-Qur'an } \\
\text { Hadits (Bulughul }\end{array}$} \\
\hline & \multicolumn{2}{|c|}{$\begin{array}{l}\text { Ulumul Quran (Attibyan) Fiqh (Fathul } \\
\text { Qorib-lanjutan) Nahwu (Mutammimah- } \\
\text { lanjutan) Shorof (Qowaidus shorfiyah- }\end{array}$} & $\begin{array}{l}\text { Fiqh } 2 \text { (Fathul } \\
\text { Muin) Ushul } \\
\text { Fiqh (As-Sulam- }\end{array}$ & \\
\hline
\end{tabular}




\begin{tabular}{|c|c|c|c|}
\hline & $\begin{array}{l}\text { lanjutan) Bhs. Arab (Al-Muhawaroh-lanjutan) } \\
\text { Tafsir (Munir-lanjutan) }\end{array}$ & $\begin{array}{l}\text { lanjutan) Hadits } \\
\text { (Bulughul } \\
\text { Marom- } \\
\text { lanjutan) }\end{array}$ & $\begin{array}{l}\text { Marom \& Munir) Bhs. } \\
\text { Arab }\end{array}$ \\
\hline & $\begin{array}{l}\text { Aswaja (Lajnah NU) } \\
\text { Akhlaq Tasawuf } \\
\text { Majelis Ilmu Sabtu } \\
\text { Tahfidz* } \\
\text { (Umum: Surat Tarawih NU, Khusus: } 30 \text { Juz) } \\
\text { Tahlil \& Yasiin }\end{array}$ & & $\begin{array}{l}\text { Majelis Ilmu Sabtu } \\
\text { Tahfidz * (Umum: Al- } \\
\text { Mulk,Al-Waqi'ah. } \\
\text { Khusus: } 30 \text { Juz) } \\
\text { Tahlil \& Yasiin } \\
\text { Tadarus Ba'da Maghrib }\end{array}$ \\
\hline \multirow{3}{*}{ IV } & Dirosat Al-Qur'an & Fiqh & \multirow[b]{2}{*}{$\begin{array}{l}\text { Tasawuf (Al-Hikam) } \\
\text { Sejarah Islam Eropa } \\
\text { Al-Qur'an (Tafsir Munir) } \\
\text { Hadits (Bulughul } \\
\text { Marom \& } \\
\text { Bhs. Arab }\end{array}$} \\
\hline & $\begin{array}{l}\text { Ulumul Quran (Attibyan) } \\
\text { Fiqh (Fathul Qorib-lanjutan) } \\
\text { Nahwu (Mutammimah-lanjutan) } \\
\text { Shorof (Qowaidus shorfiyah-lanjutan) } \\
\text { Bhs. Arab (Al-Muhawaroh-lanjutan) } \\
\text { Tafsir (Munir-lanjutan) }\end{array}$ & $\begin{array}{l}\text { Fiqh } 2 \text { (Fathul } \\
\text { Muin) Ushul } \\
\text { Fiqh (As-Sulam- } \\
\text { lanjutan) Hadits } \\
\text { (Bulughul } \\
\text { Marom- } \\
\text { lanjutan) }\end{array}$ & \\
\hline & \multicolumn{2}{|c|}{$\begin{array}{l}\text { Aswaja (Lajnah NU) Akhlaq Tasawuf Majelis Ilmu } \\
\text { Sabtu Tahfidz * (Umum: Surat Tarawih NU, Khusus: } 30 \text { Juz) } \\
\text { Tahlil \& Yasiin }\end{array}$} & $\begin{array}{l}\text { Majelis IImu } \\
\text { Sabtu Tahfidz* } \\
\text { (Umum: Ar-Rohman. } \\
\text { Khusus: } 30 \text { Juz) Tahlil } \\
\text { \& Yasiin Tadarus } \\
\text { Ba'da Maghrib }\end{array}$ \\
\hline
\end{tabular}

\section{Sumber: Data Primer Pesantren (Diolah)}

\section{Catatan: Sertifikat keahlian tambahan}

\section{Baca tulis Al-Qur'an 2. Tahfidz 3. Juz 30 4. Imam Tarawih 5. Yasiin dan Tahlil}


Tabel 3

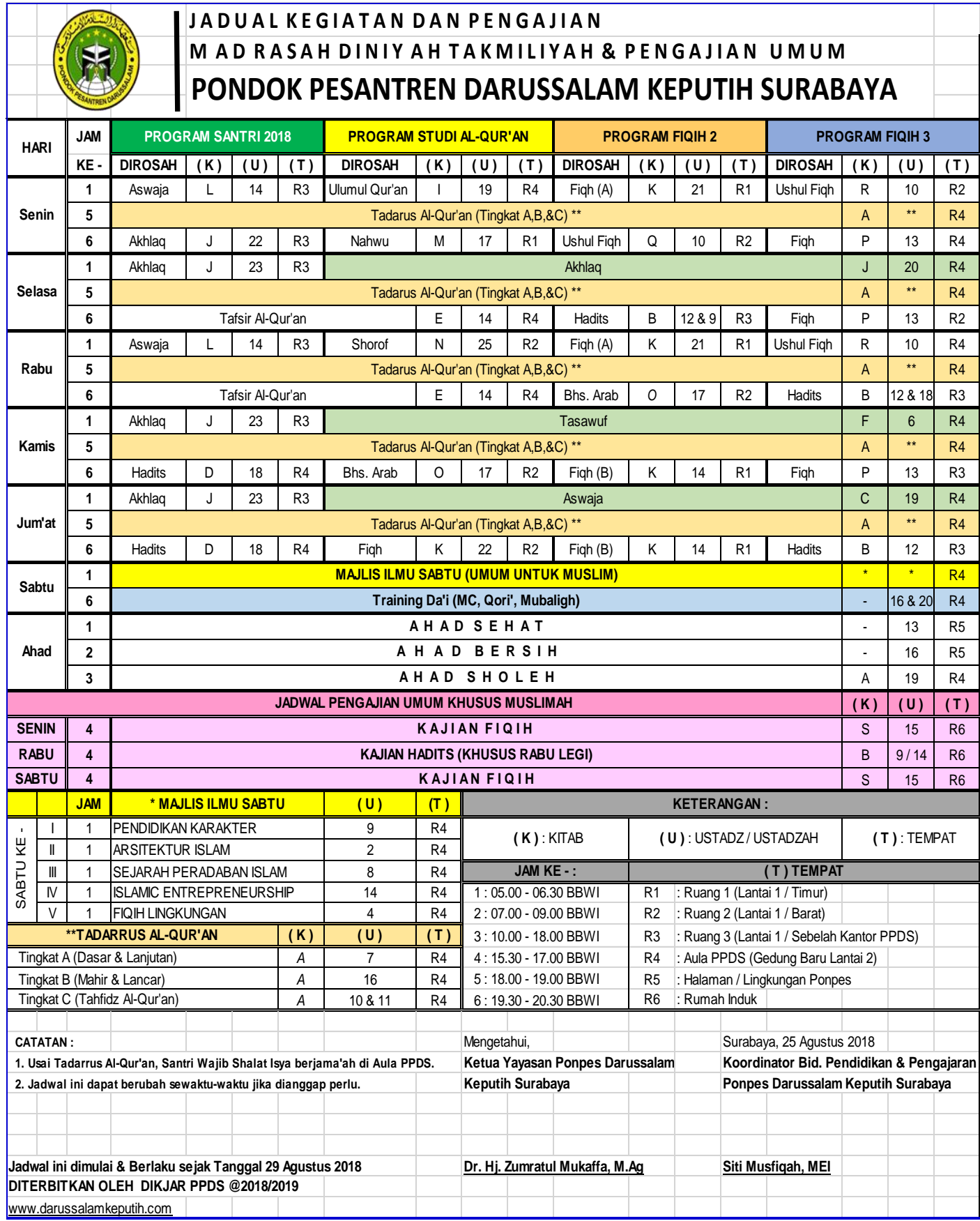

